\title{
DESTINATION IMAGE IN THE COVID-19 CRISIS: HOW TO MITIGATE THE EFFECT OF NEGATIVE EMOTIONS, DEVELOPING TOURISM STRATEGIES FOR ETHNOCENTRIC AND COSMOPOLITAN CONSUMERS
}

\author{
IMAGEN DE DESTINOS EN LA CRISIS DEL COVID-19: CÓMO MITIGAR EL EFECTO \\ DE EMOCIONES NEGATIVAS DESARROLLANDO ESTRATEGIAS TURÍSTICAS PARA \\ CONSUMIDORES ETNOCÉNTRICOS Y COSMOPOLITAS
}

\author{
Lorena Gómez-Díaz \\ Classification: Conceptual paper \\ Received: July 1, 2020 / Revised: October 2, 2020 / Accepted: October 30, 2020
}

\begin{abstract}
This paper analyses the role of destination image during the COVID-19 crisis in order to offer practical recommendations for destination managers in developing countries. It is argued that the negative emotions triggered during the pandemic will have a direct impact on destination image. Targeting ethnocentric and cosmopolitan consumers is suggested as a potential mitigation strategy, as these consumer's predispositions might moderate the adverse effect. The paper opts for an argumentation and conceptual model based on a thorough literature review of destination image, negative emotions, consumer ethnocentrism and consumer cosmopolitanism. It is argued that the negative emotions triggered by the COVID-19 crisis have a direct influence on destination image. Furthermore, the consumer predispositions of consumer ethnocentrism and consumer cosmopolitanism moderate the impact of destination image on tourism outcomes, such as, intentions to visit and willingness to recommend a destination. Managers must distinguish the affective and cognitive components of destination image in order to identify attributes relevant to the development of tourism strategies. This study provides a theoretical and conceptual foundation for differentiating between the cognitive and affective components of destination image, which allows for identifying the impact of negative emotions in a time of crisis. The study further enables managers to develop segmentation strategies based on consumer ethnocentrism and cosmopolitanism.
\end{abstract}

Keywords: destination image, negative emotions, COVID-19 crisis, consumer ethnocentrism, consumer cosmopolitanism, tourism

\section{Resumen}

Este artículo analiza el papel de la imagen de un destino turístico durante la crisis del COVID-19 con el fin de ofrecer recomendaciones prácticas para los gestores de destinos turísticos en países en desarrollo. Se argumenta que las emociones negativas desencadenadas durante la pandemia tendrán un impacto directo en la imagen de destinos turísticos. Se sugiere dirigirse a los consumidores etnocéntricos y cosmopolitas como una posible estrategia de mitigación, ya que estas predisposiciones de los consumidores podrían moderar el efecto adverso. En este estudio se opta por un modelo conceptual y de argumentación basado en una revisión bibliográfica exhaustiva sobre la imagen del destino, emociones negativas, y las orientaciones etnocéntricas y cosmopolitas de consumidores. Se argumenta cómo

a University of Vienna, ATC Consultants and Head of Communications of Coffee Break with Researchers. Vienna, Austria. Email: Lorenagomezd@gmail.com 
las emociones negativas desencadenadas por la crisis del COVID-19 tienen una influencia directa en la imagen de destinos turísticos. Además, las predisposiciones de los consumidores al etnocentrismo y el cosmopolitismo moderan el impacto en la imagen del destino y en el desempeño de indicadores de turismo, tales como intenciones de visitar un destino y la voluntad de recomendación. Los gestores de turismo deben distinguir los componentes afectivos y cognitivos de la imagen de sus destinos turísticos con el fin de identificar atributos relevantes para el desarrollo de estrategias turísticas. Este estudio proporciona una base teórica y conceptual para diferenciar los componentes cognitivos y afectivos de la imagen de destinos turísticos, lo que permite identificar el impacto de emociones negativas en un momento de crisis. Este análisis permite además a los gerentes desarrollar estrategias de segmentación basadas en orientaciones etnocéntricas y el cosmopolitas del consumidor.

Palabras clave: imagen de destino, emociones negativas, crisis COVID-19, etnocentrismo del consumidor, cosmopolitismo del consumidor, turismo

\section{Introduction}

The COVID-19 pandemic has generated an unprecedented global crisis with consequences at all societal levels that are yet to be foreseen. The UNWTO expects an $80 \%$ decrease in global tourism in 2020, since all tourism destinations had to put several restrictions in place (UNWTO, 2020). Also, there are signs of a long and slow recovery given that tourists have health and safety concerns and are also expected to be cautious about spending money (Gössling et al., 2020). Developing countries are significantly affected by this crisis, not only because health systems are weaker and lacking appropriate capacities to deal with such a situation, but also because the economy of the majority of these countries heavily relies on international tourism, which practically disappeared between March and May 2020. Although recent reports show a positive recovery in the years ahead given the resilient character of the tourism industry, several challenges are to be overcome as the global economic contraction will have consequences in the long term (UNWTO, 2020).

With this in mind, the purpose of this paper is to provide a conceptual model that allows tourism destinations to identify opportunities for product development and marketing communications in times of global economic recession. To achieve this purpose, an analysis of destination image is first presented in order to identify the key elements that constitute the overall image of a destination, influencing tourist perceptions and behaviour. Destination image is understood as "the perceptions of individual destination attributes and the holistic impression made by a destination" (Echtner \& Ritchie, 1993, p. 43). Furthermore, when analysing destination image, it is important to distinguish the cognitive and affective components as they might influence perceptions and behaviour differently. This distinction can be particularly relevant for developing countries because they usually rely on affective elements for tourism strategies. It is argued that the affective component is mainly formed by the emotional responses and feelings triggered by a destination (Baloglu \& McCleary, 1999; White \& Scandale, 2005). Moreover, some scholars also argue that the emotional state at the time of making a decision highly influences the affective component of destination image (Zeugner-Roth \& Žabkar, 2015). As negative emotions are usually triggered and collectively perceived in times of crisis (Madera \& Smith, 2009), it is to be expected that the negative emotions triggered during the COVID19 crisis will have a direct impact on destination image. Based on these theoretical assumptions and drawing from the theoretical framework of the Appraisal Tendency Framework (Lerner \& Keltner, 2000), an analysis of negative emotions influencing destination image will be provided.

Second, based on an analysis of the consumer predispositions of ethnocentrism and cosmopolitanism, possible behavioural responses of tourists in times of crisis are suggested, which might be useful for tourism development strategies and target segmentation. Consumer ethnocentrism is understood as "consumer beliefs about the appropriateness of purchasing foreign-made products" (Shimp \& Sharma, 1987, p. 280). Consumer cosmopolitanism is defined as "the extent to which a consumer exhibits open-mindedness towards foreign countries and cultures, appreciates the diversity brought about by the availability of products from different national and cultural origins, and is positively disposed towards consuming products from different countries" (Riefler et al., 2012, p. 287). Ethnocentric consumption tendencies can be expected since consumers are inclined to support their local economy (Siamagka \& Balabanis, 2015), whilst cosmopolitan consumers might support foreign developing countries as the result of sharing values within the global community (Cleveland \& Laroche, 2012). As consumer predispositions influence consumer perceptions 
and further behaviour (Zeugner-Roth et al., 2015), both consumer cosmopolitanism and consumer ethnocentrism might moderate the impact of destination image on tourism behavioural outcomes, such as willigness to visit and intentions to recommend.

The proposed analysis aims at providing twofold practical recommendations for destination managers in developing countries. First, the paper suggests implications for destination image management with regards to identifying how and when it is advisable to use affective elements in communication strategies. Second, the analysis is followed by recommendations for tourism product development and target segmentation based on ethnocentric and cosmopolitan consumer profiles. By developing tourism products and communication strategies focused on consumers' values, more opportunities for delivering memorable tourism experiences could be generated (Goossens, 2000). As noted by Lee et al., (2011), the added value to tourism experiences will increase motivation to travel again to the same destination and to recommend it as well. The novelty of our research is based on the analysis of basic emotions and the moderating effects of consumer ethnocentrism and consumer cosmopolitanism in the tourism field, which have not been examined simultaneously to the best of our knowledge.

The paper is structured as follows. First, it entails an analysis of destination image, in which the importance of considering its affective and cognitive components separately, but not independently, is argued. Considering these components separately is essential for conceptual and managerial implications because this would allow for identifying strategic aspects to be explained and improved in a specific way (Stylidis et al., 2017; Zeugner-Roth \& Žabkar, 2015). Second, an analysis of the consumer predispositions of ethnocentrism and cosmopolitanism in times of crisis is presented. This analysis is based on the notion that tourists are to be influenced by the perception of how much they should support the local/foreign economy in difficult economic times (Chan et al., 2010). Third, a conceptual model will be presented in order to integrate the arguments provided. It is argued that both consumer ethnocentrism and consumer cosmopolitanism moderate the influence of destination image on behavioural tourism outcomes. Finally, a section with conclusions, implications and limitations will be presented. This section highlights the fact that identifying tourism behavioural trends is crucial for tourism product development and marketing communication strategies. These insights are highly valuable for generating memorable experiences that add value to tourists, which can compensate for the difficult times that the industry is facing and might accelerate its economic recovery.

\section{Literature Review}

\section{Destination Image}

Destination image is a highly investigated construct in international marketing and tourism research. Empirical measurements however are rather complex since consumers' overall perceptions of a destination may be either favourable or unfavourable depending on the specific conditions of a place, which have high statistical variance (Baloglu \& McCleary, 1999; Beerli \& Martin, 2004; Echtner \& Ritchie, 1993; Gallarza et al., 2002; Li et al., 2015; Mossberg \& Kleppe, 2005; Pike, 2002; Roth \& Diamantopoulos, 2009; Zeugner-Roth \& Žabkar, 2015). There are also conceptual issues with regards to the measurement scales. Some of them fail in operationalizing affective components, as pointed out by Roth and Diamantopoulos (2009). For example, an often-used item "people are likeable" does not measure the same aspect as the item "I like the people from that place". The former measures what a person might think about the people from a particular place and the latter what a person might feel about the people from a particular place. These measurement issues indicate how complex the measures can be and also the affective components may be assessed as cognitive ones (Roth \& Diamantopoulos, 2009).

The cognitive and affective components of destination image are simultaneously involved in the formation of the overall image of a destination (Baloglu, \& McCleary 1999; Echtner \& Ritchie, 1993). On the one hand, the cognitive component is related to the beliefs and knowledge about a destination, which helps to create a mental representation of the place (Baloglu \& McCleary, 1999; Pike, 2002; Perpiña et al., 2019; Stylidis et al., 2017). This component refers to the resources and facilities of a tourism destination involving aspects such as the scenery, climate, accommodation facilities, restaurants, and historical and cultural attractions (Stabler, 1995). Empirically, it has usually been assessed through some of the following nine dimensions: natural resources, general infrastructure, tourism infrastructure, tourism leisure and recreation, culture, economic factors, natural environment, social environment and atmosphere (for reviews see Li et al, 2015; Pike, 2002; Stylidis et al., 2017). Studies have identified empirical issues with regards to the assessement of the cognitive component in destination image (e.g. Perpiña et al., 2019), who also revealed that empirical issues might have an effect on risk assessment. On the other hand, the affective component of destination image concerns the emotional responses and feelings towards a destination (Baloglu \& McCleary, 1999). These affective responses can vary highly depending on the specific 
travel stage (pre-visit, on-site, and post-visit) and on each individual. Therefore, it is difficult to specify their impact from a comprehensive perspective (Baloglu \& McCleary, 1999; Stylidis, et al., 2017). Empirically, affective measures are usually based on the affective evaluations of four dimensions (pleasantness, arousement, relaxation and excitement) (Stylidis, et al., 2017). As Zeugner-Roth and Žabkar (2015) suggest, the affective component is particularly relevant during the evaluation and final decision-making of a specific destination. This is because, although several factors can play an important role in the decision of a travel destination, such as the overall perception, available attractions, accommodation standards, etc., at the time of making the decision, all these factors are balanced out by an affective component: tourists simply want to travel or do not want to travel that particular destination (Zeugner-Roth \& Žabkar, 2015). This is why, scholars argue that the affective dimension of destination image could be even more important than the cognitive dimension when explaining tourists' decisions (Roth \& Diamantopoulos, 2009; White \& Scandale, 2005).

Although destination image is a single construct with two components, these two components should be studied separately, but not independently (Stylidis et al., 2017; Zeugner-Roth \& Žabkar, 2015). Consequently, although one could argue that the first level of response to a destination is affective and these emotional responses influence subsequent attitudes and behaviour (Stylidis et al., 2017), one could also argue that people's affective evaluation of a place largely depends on their previous knowledge of that place (Boo \& Busser, 2005). Therefore, both affective and cognitive components can be seen as intertwined, and depend on specific circumstances of both the tourists' perceptions and situations. Several empirical studies have investigated the influence of the cognitive and affective components (Baloglu \& McCleary, 1999; Lin et al., 2007; Zeugner-Roth \& Žabkar, 2015). They have found, for instance, that tourists can develop feelings about a place after they have cognitively evaluated it without even having been there (Lin et al., 2007). This means that, even though the image a tourist forms about a destination is composed of a cognitive and an affective component, these two components can influence further evaluations and behaviour in different ways. They should thus be considered distinctively. This distinction can be quite relevant for destinations that have heavily relied on affective components for their strategies, such as developing countries.
Destination Image in Developing Countries. Is the Affective Component so Effective in Times of an Economic Crisis?

The distinction between the affective and cognitive components of destination image can be particularly important for developing countries. They might suffer from negative cognitive evaluations concerning the lack of infrastructure and general facilities. However, most of them have very positive evaluations with regards to the overall experience due to affective reasons (Campo \& Alvarez, 2010). This factor can explain why several developing countries have been ranked as "top destinations" in the last decade, since tourist satisfaction and overall experience is evaluated positively, whilst several cognitive dimensions might not be as highly ranked (Forbes, 2018). However, heavily relying on affective elements for tourism development can backfire in times of crisis. During times of crisis, negative emotions can easily be triggered and remain in collective perceptions for long periods of time, overshadowing the influence of positive emotions (Mamun \& Ullah, 2020). At this point, it is important to consider that emotions work as a tool for action and strongly influence perceptions and decisions (Lerner \& Keltner, 2001; Lerner et al., 2015). Therefore, understanding how and why these emotional reactions are generated in a specific situation can be insightful when developing more effective destination tourism strategies. Given that emotional reactions can be considered part of the affective component of a country's image, we argue that it is crucial to examine it more carefully in strategies appealing to that component.

Affective components have been highly relevant for tourism marketing campaigns overall, but particularly for Latin American countries. For instance, countries such as Colombia or Peru have developed consistent tourism marketing communication campaigns based on creative concepts of enjoyable experiences for tourists based on sensory pleasure. In a recent tourism marketing campaign, Peru launched the slogan "the richest country in the world" based on the country's reputation as a "world-class cultural and culinary destination" (Marketing Comm News , 2017). Colombia's latest campaign "sabrosura" aims at reinforcing positive attributes of warmth, happiness and rhythm, focused on the country's image of friendliness and joy (La Republica, 2018). These strategies have proven to be quite successful for both countries. Peru is one of the leading tourism destinations in South America with the highest increase of incoming tourists in the past years and a tourist satisfaction rate of 94\% (UNWTO, 2016). Colombia has been 
ranked as the number one "trending tourism destination in the Americas" following an unprecedented growth in 2019 (ProColombia, 2019). However, given the uncertainty of tourists regarding these countries'overall situation after the COVID-19 crisis, it would be advisable to reevaluate the effectiveness of this type of strategy for attracting tourists in the global market. This is because perceptions of uncertainty, unpredictability and uncontrollability are intrinsically linked to the negative emotions of fear, sadness and anger. These are the basic emotions, which are usually and collectively triggered in times of crisis, influencing people's evaluations and behaviour tremendously (Madera \& Smith, 2009). According to Lerner and Keltner $(2000 ; 2001)$, by analysing the core appraisal, goal-directed process, together with the action tendency of emotions, important tendencies of individual perceptions and behaviour can be identified and strategies can be adapted accordingly.

\section{The Impact of Negative Emotions on \\ Destination Image: Fear, Sadness and Anger}

Although the use of affective components has been proven to be effective for promoting tourism for destinations, it is important to consider that they might not be that effective in times of crisis, due to the negative emotions triggered in such a situation. In an unprecedented crisis like the one brought by the COVID-19 pandemic, a general sense of situational uncertainty, unpredictability and uncontrolability is generated (Mamun \& Ullah, 2020). Uncertainty, unpredictability and uncontrollability are the appraisal tendencies associated with the basic emotions of fear, sadness and anger, respectively (Lerner $\&$ Keltner, 2001; Lerner et al., 2015). These three emotions are directly linked to the survival action instincts of fleeing, freezing and fighting (Goleman, 2006). This explains why these are the most common emotions triggered in times of crisis. Drawing from the Appraisal Tendency Framework (Lerner \& Keltner, 2000), it is argued that analysing the appraisal and action tendencies of these emotions allows for a better understanding of tourists' decisions and behaviour since most human decisions are driven by emotions (Lerner et al., 2015).

Firstly, fear -understood to be an unpleasant state caused by a perception of threat of danger- is associated with the perception of negative events as being unpredictable, uncertain and under situational control. Under a state of fear, individuals have action tendencies of fleeing or hiding immediately, escaping from the situation and perceiving high risk (Lerner \& Keltner, 2000). Secondly, sadness -understood to be a sense of loss and the misfortune of an undesirable outcome by situational factors beyond anyone's control- is associated with the perception of negative events as being unpredictable and under human control. Sad people have action tendencies of increasing systematic processing and perceiving low risk (Lerner et al., 2015). And thirdly, anger -understood to be a negative unpleasant state of annoyance, displeasure, or hostility, which is also the antecedent of frustration- is associated with the perception of negative events as being predictable, under human control, and brought about by others. Angry people have tendencies of aggressive and immediate action, their heuristic and stereotypical processing increases, and their perceptions of risk are lower (Lerner \& Keltner, 2000).

It might seem difficult for a destination marketer to know what to do in times of crisis when the entire tourism industry is wondering the same. Appealing to emotional arguments which sell enjoyable experiences can simply become common place, in which differentiation can hardly take place. Although it is important to always consider affective elements in tourism marketing communication, it is also highly relevant to consider cognitive aspects that compensate for the appraisal of a negative emotion. For instance, the emotion of sadness refers to a "sense of not keep losing something"; therefore, what sad people need to experience in order to feel less sad is a "sense of having something or finding a connection to hold on to". In the same way, people who are feeling fear have a sense of uncertainty and lack of control; therefore, they need to experience certainty and control that makes them avoid risk (Lerner et al., 2015). Table 1 summarizes the analysis.

\section{Consumer Predispositions for Target Segmentation in a Global Tourism Crisis}

\section{Consumer Ethnocentrism. When Buying \\ Local Seems the Right Thing to Do.}

As seen in the handling of previous crises, developed countries are expected to encourage their citizens to buy domestic products in order to protect local businesses (Chan et al., 2010). Although the survival of emerging countries is also crucial for the global market, significant efforts are to be put into strengthening local capacities and promoting domestic production and consumption. This means that global consumers are persuaded to buy local and travel locally, consequently supporting economic nationalism and fostering tendencies of ethnocentric consumption (Gössling et al., 2020). Consumer ethnocentrism has widely been documented in the literature explaining the preferences of local products (Wang \& Zhen, 2004; Zeugner-Roth et al., 2015). 
Table 1. Analysis of Negative Emotions

\begin{tabular}{|c|c|c|}
\hline \multicolumn{3}{|c|}{ Negative Emotions } \\
\hline \multicolumn{3}{|c|}{ Definition } \\
\hline $\begin{array}{l}\text { Negative unpleasant state of annoyance, } \\
\text { displeasure, or hostility. }\end{array}$ & $\begin{array}{l}\text { Unpleasant state caused by a threat of danger, } \\
\text { pain, or harm when being too close to a potentially } \\
\text { contaminating object. }\end{array}$ & $\begin{array}{l}\text { Loss and misfortune of an undesirable outcome by } \\
\text { situational factors beyond anyone's control. }\end{array}$ \\
\hline $\begin{array}{l}\text { Perceive negative events } \\
\text { as predictable, under } \\
\text { human control, and } \\
\text { brought about by } \\
\text { others. }\end{array}$ & $\begin{array}{l}\text { Perceive negative events } \\
\text { as uncertain and } \\
\text { under situational } \\
\text { control. }\end{array}$ & $\begin{array}{l}\text { Perceive negative events as unpredictable and } \\
\text { under human control. }\end{array}$ \\
\hline \multicolumn{3}{|c|}{ Action tendency } \\
\hline Perception of low risk. & Perception of high risk. & Perception of low risk. \\
\hline \multicolumn{3}{|c|}{ Possible Actions to Mitigate Influence } \\
\hline $\begin{array}{c}\text { Sense of action - having an active role - getting } \\
\text { achievements. }\end{array}$ & $\begin{array}{l}\text { Sense of certainty, awareness and situational } \\
\text { control. }\end{array}$ & $\begin{array}{l}\text { Sense of not keep losing - having something to hold } \\
\text { on to - feeling connections. }\end{array}$ \\
\hline
\end{tabular}

Source: Lerner et al., 2015 and Lerner and Keltner, 2000.

Ethnocentric consumers tend to prefer domestic products for economic motives, such as the fear that opting for foreign alternatives would threaten the domestic industry (Verlegh, 2007). Thus, in terms of a global economic crisis, when feelings and collective sentiments of fear are generated (Mamun \& Ullah, 2020), it is to be expected that consumers will show tendencies of ethnocentric purchasing behaviour.

Several studies have been conducted about how ethnocentric tendencies can even become a moral obligation where spending at home feels like "the right thing to do" (Shimp \& Sharma 1987; Wang \& Zhen, 2004). Ethnocentric tendencies can be analysed as information cues that influence the image of local products positively, and that of foreign products negatively (Zeugner-Roth,Žabkaretal.,2015).Ethnocentrismis thus a predisposition, which is more pronounced in developed countries, as consumers tend to highly appreciate local production (Chan et al., 2010). This is also a tendency used in destination image strategies for tourism marketing. For instance, Austria, a developed country with a comparatively positive balance in the handling of the COVID-19 crisis with respect to the number of cases in Europe, has started to strongly encourage people living in Austria to enjoy regional tourism (Austrian Official Travel Portal, 2020). Austria's current strategy also focuses on providing frequent and up-to-date information on the COVID-19 situation and offering virtual tours to foreign tourists.

\section{Creating More Conversations: Consumer Cosmopolitanism as an Opportunity for Developing Countries.}

In times of economic crisis, consumers also show a predisposition to support other people, showing openness and affinity towards global solidarity (Kyriakidou, 2008). As several studies have shown, this type of tendency can be analysed within the notion of cosmopolitanism, in which individuals consider themselves to be citizens of the world, having the planet as a home rather than a particular country (Hill \& Hult, 2019). The investigation of consumer cosmopolitanism has provided insightful findings with regards to a global culture of consumption (Cleveland \& Bartsch, 2019). However, its research in the field of tourism is relatively scarce. Studies having an anthropological perspective (Salazar, 2010), conceptual perspective (Johnson, 2014) and critical perspective (Mota, 2017) can be found. According to Salazar, it is crucial that cosmopolitan tourists feel familiar in destinations, in the sense that they can see themselves connected to their life-world and engage with the local culture (Salazar, 2010). According to Hannerz, "the perspective of the cosmopolitan must entail relationships to a plurality of cultures, including an orientation, a willingness to engage with the other" (Hannerz, 1990, p. 239). Cosmopolitanism is associated with a willingness to engage in daily life practices, rendering the concept to be holistic and multidimensional. Thus, when addressing cosmopolitan 
consumers, it is crucial to consider comprehensive strategies, in which not necessarily traditional marketing through conventional ads is generated. Instead, interesting tourism products that become relevant to consumers are recommended, as well as communication through relevant messages in targeted channels.

Zeugner-Roth, Žabkar and Diamantopoulos have empirically shown that both consumer ethnocentrism and consumer cosmopolitanism influence consumers' evaluations, and their willingness to buy domestic and foreign products (Zeugner-Roth et al., 2015). In both cases, emotional responses would influence the predisposition towards an event in a favourable or unfavourable manner, given that both constructs have an affective component. Thus, it can be expected that when emotions are highly aroused, both consumer predispositions will have an effect on the impact of destination image as is hypothesized and explained below.

\section{Conceptual Model}

The discussion above sets the conceptual model illustrated in Figure 1. It is argued that negative emotional responses as a result of the COVID-19 crisis will impact destination image. It is further argued that the predispositions of consumer ethnocentrism and cosmopolitanism can also influence the impact of destination image and consequent tourism outcomes, moderating the relationship. It is suggested that willingness to visit (Chen \& Phou, 2013) and intentions to recommend (Chi \& $\mathrm{Qu}, 2008$ ) might be relevant outcomes to be investigated, as they are key indicators of successful destination development.

\section{Conclusion and Implications}

During and after the COVID-19 crisis, the tourism sector is expected to be negatively impacted the hardest world- wide, and its recovery is estimated to once again become an important pillar of the global economy (UNWTO, 2020). Given that destinations in developing countries will have to compete in a global tourism market, it is important to identify key elements that strengthen their destination images and provides them with more competitive advantages. In this paper a conceptual model was presented by analysing the notions of destination image and the consumer predisposition of ethnocentrism and cosmopolitanism. This can provide practical recommendations for tourism marketers in developing countries. It was argued that destination image is influenced by negative emotions, and its impact on intentions to visit and willingness to recommend is moderated by consumer ethnocentrism and consumer cosmopolitanism.

It has been argued that destination image is a construct with two components, a cognitive and an affective, the latter being more relevant for tourists when deciding on a travel destination. Therefore, considering which emotions are triggered when a person makes a decision is highly relevant, particularly in times of crisis. Based on this notion, an analysis of fear, sadness and anger has been provided. The use of cognitive evaluations mitigating the effect of negative emotions has also been recommended. This is because negative emotions might have a stronger influence on evaluations and thus, they might overshadow the efforts of communication entirely based on positive affect.

In addition, it was argued that the consumer predispositions of ethnocentrism and cosmopolitanism might have a strong influence during economic hardship, as individual evaluations might be shaped by the perception on how much people should support the local/foreign economies. In both cases, identifying behavioural trends on different media platforms is highly recommendable as this might increase the possibilities to interact and create conversations with different audiences. As destination

Figure 1. Conceptual Model

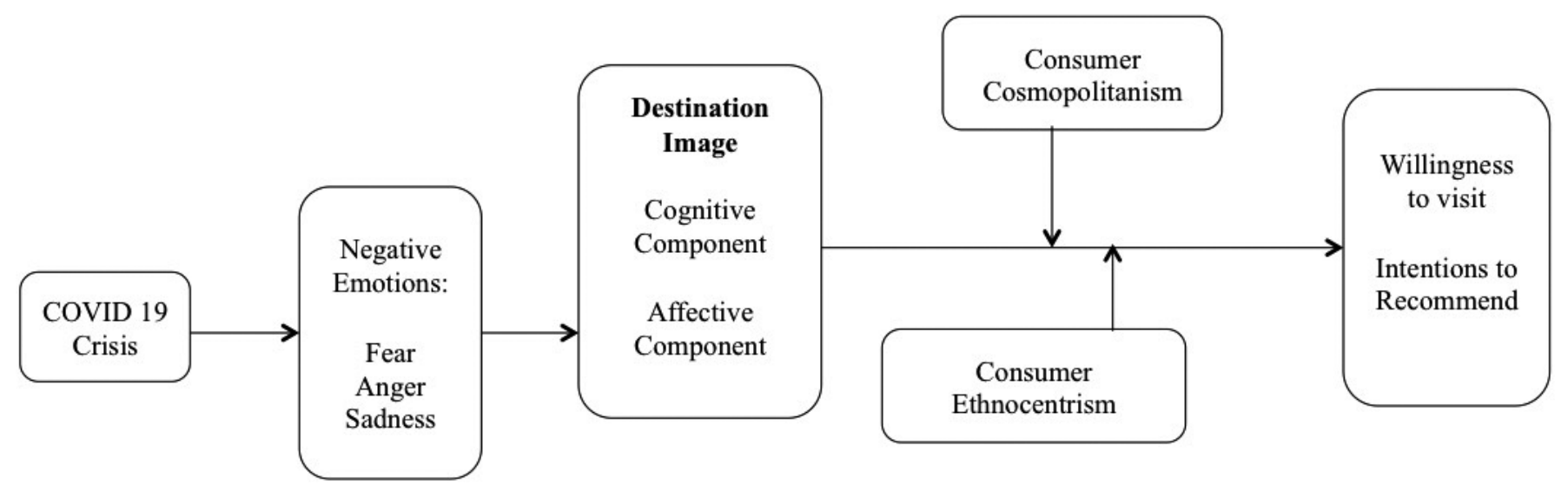

Source: The author. 
image is a multidimensional construct, highly influenced by affective aspects as well as individual predispositions, it is important to focalize efforts in a targeted manner. Analysing which cognitive aspects of the destination are to be communicated and how to communicate them to segmented target audiences should thus be addressed.

\section{Managerial Implications}

The presented analysis has several managerial implications for tourism developers and marketers. First, it is recommendable to understand the notion of destination image from a comprehensive perspective where the affective component plays an important role. This would allow for making the distinction between cognitive and affective attributes of the destination, which can be fostered in communication efforts. Moreover, it is essential to consider the negative emotions triggered in an economic crisis. In this regard, considering Lerner et al., 2015, emotions can strongly influence evaluations and behaviour; therefore, identifying how these emotional responses can be mitigated is highly recommended. By analysing the appraisal tendencies and action tendencies of emotions, specific insights can be identified for product development and marketing communication strategies. Table 1 is presented as a guiding tool for managers to consider when dealing with negative emotions, so they can find possible actions to mitigate their influence.

These considerations have useful implications for developing activities to engage communities. For instance, if consumers show signs of sadness, they will seek information on how to feel connected to a specific social affiliation such as a social media group or community, which can make them feel better. Consequently, if marketers know that people in their target group feel sad, they could develop strategies for creating social media groups or activities in order to develop a sense of connectedness and solidarity. In the case of fear, people need a sense of certainty and control. In this regard, marketers could develop platforms to provide up-to-date information about security risks, precautions and safety, while ensuring a pleasant stay. Thus, a more in-depth analysis of the type of emotions tourists might be feeling when evaluating a destination could be insightful in order to identify which type of activities should be created or which unique attributes of the destination are communicated. With respect to the latter point, an in-depth analysis of social media trends influencing tourists is highly recommended since these are the most common source of information shaping their opinion.

Regarding consumer predispositions, it is crucial to acknowledge that ethnocentric tendencies can be seen as challenging, but also as an opportunity for developing countries. Targeting foreign tourists from developed countries with direct and traditional advertising in the mass media could be seen as slightly ineffective since their own local governments have deployed this strategy. Therefore, traditional marketing should also focus on fostering local tourism and strengthening local capabilities. This does not mean, however, that the prospects to increase incoming tourism from developed countries are to be neglected. There are several opportunities to keep communications with global tourists open through different digital channels, in which the destination image stays relevant.

Consequently, understanding tourism trends in social media is crucial when identifying possibilities to create conversations online. Through establishing permanent and motivating communication alternatives, the image of the destination might remain relevant and memorable for a longer period of time. Communication strategies should not be based only on affective components, but instead also on smart connections created over time and through interesting conversations on online platforms.

When addressing cosmopolitan consumers for tourism development strategies, several aspects should be considered. First, conducting in-depth research into interests and affinity for tourism product development is important, since what is delivered as a tourism experience is what actually matters, and will consequently be recommended. Holistic experiences adding value constitute a key element for generating word of mouth and first hand recommendations (Goossens, 2000). This aspect is particularly important for cosmopolitan consumers, as the notions of connectedness and belonging in the global community are highly valued. In fact, during the times of "hard lockdowns" in Europe, multiple virtual community activities where generated, focusing on social connections, a global community and different aspects of consciousness. Several cosmopolitan characteristics, such as openness toward other people and their willingness to explore, learn and help other cultures (Hannerz, 1990) can be identified in these groups. Importantly, the holistic experience delivered by a destination should also be consistent with cosmopolitan values; hence, moving beyond marketing communication, the delivery of the tourism brand promise should be associated with the actual performance of a positive cosmopolitan tourism experience. Therefore, destinations should focus on strengthening delivering capacities in tourism products, tourism experiences, and the overall perceived value.

Another aspect to be considered when targeting cosmopolitan consumers for tourism development is associated with credible communication strategies and affinity. 
Salazar found that the cross-cultural interpretation delivered by tourism guides is essential to translate cultural aspects for tourists, "making the unfamiliar, familiar" (Salazar, 2010). A familiar story told in an interesting manner can link cultural aspects of a destination to the cosmopolitan values of a tourist, which can then turn into something meaningful and create a special bond in a person's mind. Thus, communication is a very important aspect for cosmopolitan consumers, but needs to be conducted thoughtfully and in a relevant manner. On the one hand, communication should not only be connected to the personal values of an individual, but it should also be conducted in a familiar way that makes the message natural with high affinity too. In this sense, understanding trends on online platforms that make tourists connect with their interests can be seen as an opportunity to identify channels for delivering messages about the destination in a way that appears natural and familiar.

The world has yet to face the various consequences of this unprecedented global crisis. However, endurance and resilience are human characteristics that are also fostering in extreme situations. The tourism industry is one of the most resilient economic sectors and will undoubtedly recover with important lessons learned from the crisis. It is important however, that developing countries make the most of the opportunities to be generated in the current situation and foster their economy and the social development as a result of them, making a virtue out of necessity.

\section{Future Research and Limitations}

The conceptual nature of the paper makes it suffer from the lack of empirical evidence supporting the hypotheses. However, given the solid theoretical foundations, it is strongly recommended that future research empirically investigate the proposed conceptual model. By identifying the specific mechanisms of moderation, more insight into the role of consumer ethnocentrism and cosmopolitanism in tourism outcomes can be established. Comparative studies in different settings between developed and developing countries are also suggested in order to examine the conditions under which the effect of each variable plays a more prominent role.

\section{References}

Austrian Official Travel Portal. (2020, June). Austria Info. https://www.austria.info/en

Baloglu, S., \& McCleary, K. (1999). A model of destination image formation. Annals of Tourism Research, 26(4), 868-897.
Beerli, A., \& Martin, J. (2004). Factors influencing destination image. Annals of tourism research, 31(3), 657681.

Boo, S., \& Busser, J. (2005). The hierarchical influence of visitor characteristics on tourism destination images. Journal of Travel and Tourism Marketing, 19(4), 5567.

Campo , S., \& Alvarez, M. (2010). Country versus destination image in a developing country. Journal of Travel \& Tourism Marketing, 27(7), 48-764.

Chan, T., Chan, K., \& Leung, L. (2010). How consumer ethnocentrism and animosity impair the economic recovery of emerging markets. Journal of Global Marketing, (23), 208-225.

Chen, F., \& Phou, S. (2013). A closer look at destination: Image, personality, relationship and loyalty. Tourism Management, 36, 269-278.

Chi, C., \& Qu, H. (2008). Examining the structural relationships of destination image, tourist satisfaction and destination loyalty: An integrated approach. Tourism Management, 29(4), 624-636.

Cleveland, M., \& Bartsch, F. (2019). Global consumer culture: Epistemology and ontology. International Marketing Review. 0265-0287

Cleveland, M., \& Laroche, M. (2012). Becoming and being a cosmopolitan consumer. Consumer Cosmopolitanism in the Age of globalization, 51-100.

Echtner, C., \& Ritchie., J. (1993). The meaning and measurement of destination image. The Journal of Tourism Studies, 2(2), 2-12.

Forbes. (2018, December 31). Sites. https://www.forbes. $\mathrm{com} /$ sites/alexandratalty/2018/12/31/the-18-best-budget-travel-destinations-for-2019/\#e09803672025

Gössling, S., Scott , D., \& Hall, M. (2020, April 17). Pandemics, tourism and global change: A rapid assessment of COVID-19. Journal of Sustainable Tourism, 1-21.

Gallarza, M., Saura, I., \& García, H. (2002). Destination image: Towards a conceptual framework. Annals of Tourism Research, 29(1), 56-78.

Goleman, D. (2006). Emotional intelligence. Bantam Books.

Goossens, C. (2000). Tourism information and pleasure motivation. Annals of Tourism Research, 27(2), 301321.

Hannerz, U. (1990). Cosmpolitans and locals in world culture. Theory, Culture and Society, 7(2/3), 237-252.

Hill , C., \& Hult, G. (2019). International business: Competing in the global marketplace. McGrawHill.

Johnson, P. (2014). Cultural literacy, cosmopolitanism and tourism research. Annals of Tourism Research, 44, 255-269. 
Kyriakidou, M. (2008). Mediated cosmopolitanism: Global disasters and the emergence of cosmopolitan solidarity. Global Studies Journal, 1(3), 123-130.

La Republica. (2018, October 10). Turismo. https://www. larepublica.co/economia/campana-de-promocion-turistica-colombia-tierra-de-la-sabrosura-esta-en-revision-2780121

Lee, J., Lee, C., \& Choi, Y. (2011). Examining the role of emotional and functional values in festival evaluation. Journal of Travel Research, 50(6), 685-696.

Lerner, J., \& Keltner, D. (2000). Beyond valence: Toward a model of emotion-specific influences on judgement and choice. Cognition and Emotion, 14, 473-493.

Lerner, J., \& Keltner, D. (2001). Fear, anger, and risk. J. . Personal. Soc. Psychol., 81, 146-159.

Lerner, J., Valdesolo, J., \& Kassam, P. (2015). Emotion and decision making. The Annual Review of Psychology (66), 799-823.

Li, J., Ali, F., \& Gon, W. (2015). Reexamination of the role of destination image in tourism: An updated literature review. e-Review of Tourism Research, 12(3-4), 191-209.

Lin, C., Morais, D., \& Kerstetter, D. (2007). Examining the role of cognitive and affective image in predicting choice across natural, developed, and theme-park destinations. Journal of Travel Research, 46(2), 183-194.

Madera, J., \& Smith, D. (2009). The effects of leader negative emotions on evaluations of leadership in a crisis situation: The role of anger and sadness. The Leadership Quarterly, 20(2), 103-114.

Mamun, M., \& Ullah, I. (2020). COVID-19 suicides in Pakistan, dying off not COVID-19 fear but poverty? The forthcoming economic challenges for a developing country. Brain, behavior, and immunity, (87) 163166

Marketing Comm News. (2017, November). https:// marcommnews.com/peru-unveils-new-peru-the-richest-country-in-the-world-marketing-campaign-atwtm-2017/

Mossberg, L., \& Kleppe, I. (2005). Country and destination image - Different or similar image concepts? The Service Industries Journal, 25(4), 493-503.

Mota, P. (2017). Tourism and the critical cosmopolitanism imagination: The worst tours in a European World Heritage city. International Journal of Heritage Studies. 25(9), 943-957.

Perpiña, L., Camprubí, R., \& Prats, L. (2019). Destination image versus risk perception. Journal of Hospitality \& Tourism Research, 43(1), 3-19.

Pike, S. (2002). Destination image analysis: A review of 142 papers from 1973-2000. Tourism Management, 23(5), 541-549.
ProColombia. (2019, December 11). PR Newswire. https:// www.prnewswire.com/news-releases/colombiaamong-the-best-places-to-visit-in-2020-300972903. html

Riefler, P., Diamantopoulos, A., \& Siguaw, J. (2012). Cosmopolitan consumers as a target group for segmentation. Journal of International Business Studies. 43, 285-305

Roth, K., \& Diamantopoulos, A. (2009). Advancing the country image construct. Journal of Business Research, 62, 726-740.

Salazar, N. (2010). Tourism and cosmopolitanism: A view from below. Int. J. Tourism Anthropology, 1(1) 1-15

Shimp, T., \& Sharma, S. (1987). Consumer ethnocentrism: Construction and validation of the CETSCALE. 24(3), 280-289.

Siamagka, N., \& Balabanis, G. (2015). Revisiting consumer ethnocentrism: Review, reconceptualization, and empirical testing. Journal of International Marketing, 23(3), 66-86.

Stabler, M. (1995). The image of destination regions: Theoretical and empirical aspects. In G. B. Goodall (Ed.), Marketing in tourism industry: The promotion of destination regions (pp. 133-159). Croom Helm, London. Stylidis, D., Shani, A., \& Belha, Y. (2017, November 16). Testing an integrated destination image model across residents and tourists. Tourism Management, 184-195.

UNWTO. (2020, May 15). News. https://www.unwto.org/ news/covid-19-may-statement-unwto-secretary-general UNWTO. (2016). Tourism and culture partnership in Peru-Models for collaboration between tourism, culture and community. World Tourism Organization.

Verlegh, P. (2007). Home country bias in product evaluation: The complementary roles of economic and socio-psychological motives. Journal of International Business Studies, 38(3), 361-373.

Wang, C., \& Zhen, C. (2004). Consumer ethnocentrism and willigness to buy domestic products in a developing country setting: Testing moderating effects. Journal of Consumer Marketing, 21(6), 391-400.

White, C., \& Scandale, S. (2005). The role of emotions in destination visitation intentions: A cross-cultral perspective. Jorunal of Hospitality and Tourism Management, 12(2), 168-178.

Zeugner-Roth, K., \& Žabkar, V. (2015). Bridging the gap between country and destination image: Assessing common facets and their predictive validity. Journal of Business Research.

Zeugner-Roth, K., Žabkar, V., \& Diamantopoulos, A. (2015). Consumer ethnocentrism, national identity, and consumer cosmopolitanism as drivers of consumer behaviour: A social identity theory perspective. Journal of International Marketing, 23(2), 1547-7215. 